
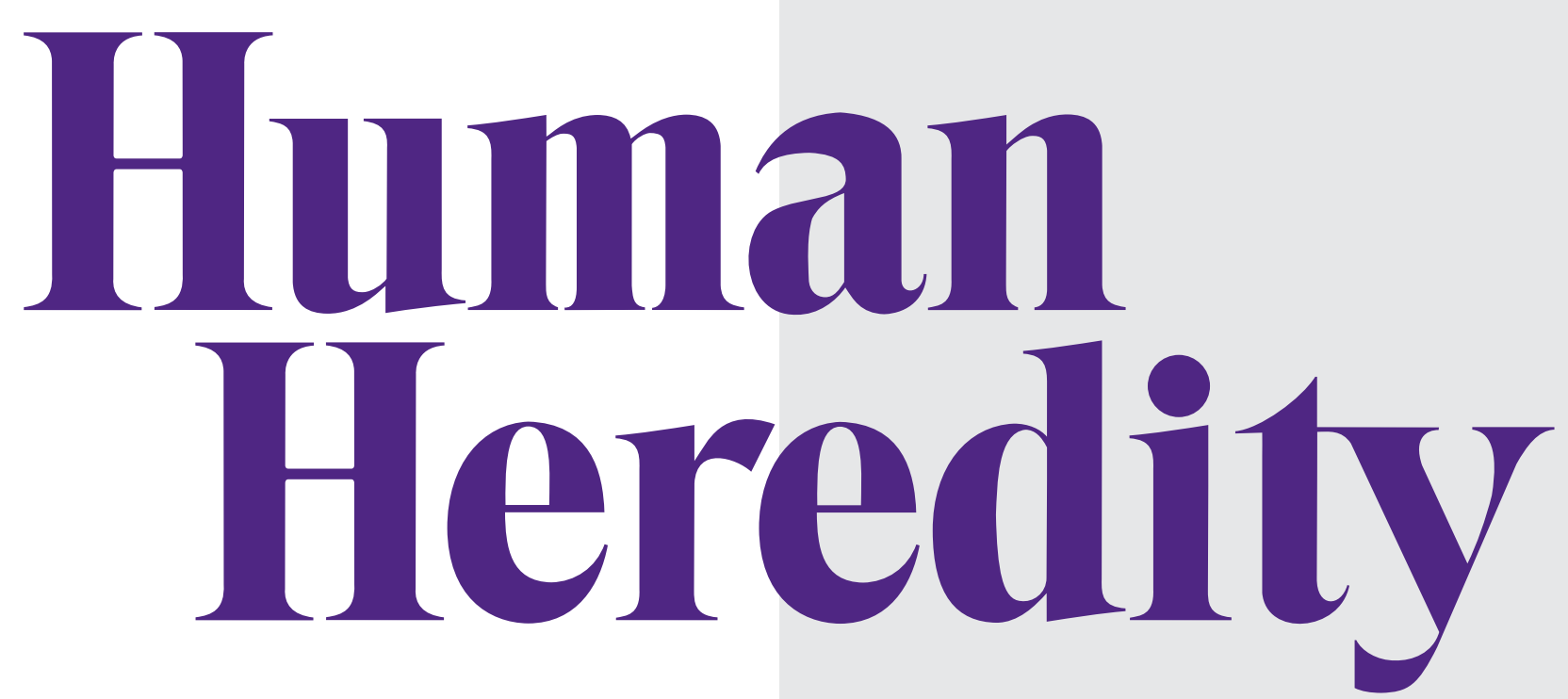

\title{
Genes and the Environment in Obesity
}

Editors

Dawson, J.A., Birmingham, Ala.

Allison, D.B., Birmingham, Ala. 


\section{An excellent source of methodological and applied genetic research}

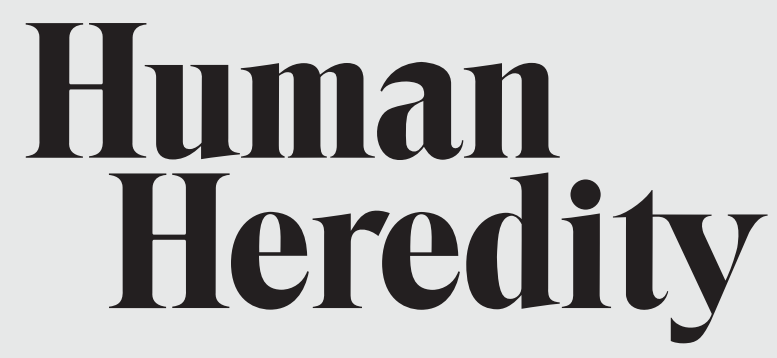

International Journal of Human and Medical Genetics

Editor-in-Chief
F. Clerget-Darpoux,
Villejuif
Senior Editor

E. Génin, Paris

Editorial Administrator

K. Montague,

New York, N.Y.

\section{Associate Editors}

\section{G. Barbujani, Ferrara \\ M. Boehnke,} Ann Arbor, Mich.

L. Brzustowicz, Piscataway, N.J.

M. de Andrade, Rochester, Minn.

M. Devoto, Philadelphia, Pa./Rome
F. Dudbridge, London

D. Gordon, Piscataway, N.J.

M. Knapp, Bonn

C. Lewis, London

Y.-Y. Teo, Singapore

H.K. Tiwari, Birmingham, Ala.

V. Vieland, Columbus, Ohio

E. Zeggini, Cambridge
Impact Factor: 1.789

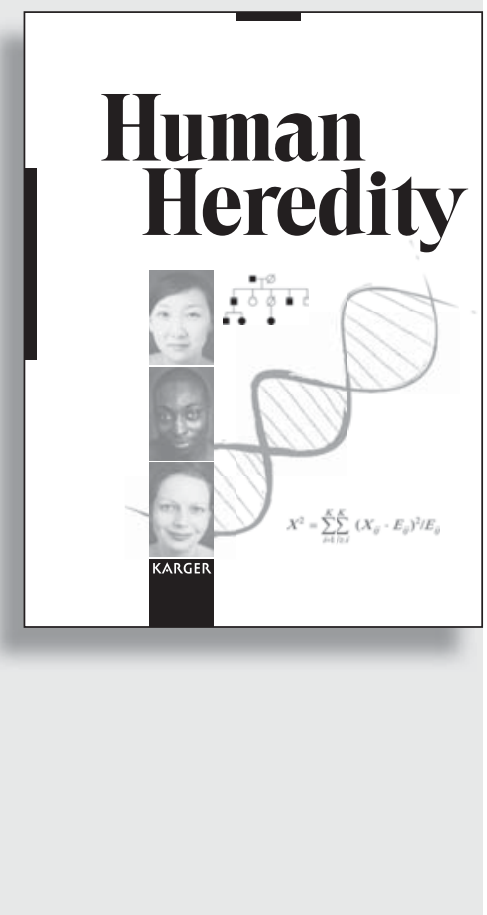

More information at

www.karger.com/hhe

- Pay-per-View and Subscriber Access to Full Text

- Full Table of Contents

- Full Editorial Board

- Free Abstracts and Selected Articles

- Online Sample Issue

- Submission/Guidelines for Authors

- Subscription Details

- Free Alert Service

- Online Library Recommendation

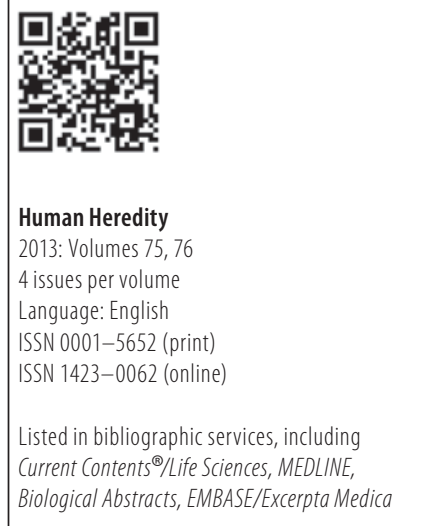

\section{Selected contributions}

- Performance of Genotype Imputations Using Data from the 1000 Genomes

Project: Sung, Y.J.; Wang, L. (St. Louis, Mo.); Rankinen, T.; Bouchard, C. (Baton Rouge, La.); Rao, D.C. (St. Louis, Mo.)

- On the Meta-Analysis of Genome-Wide Association Studies: A Robust and Efficient Approach to Combine Population and Family-Based Studies: Won, S. (Seoul); Lu, Q. (East Lansing, Mich.); Bertram, L. (Charlestown, Mass./Berlin); Tanzi, R.E. (Charlestown, Mass.); Lange, C. (Boston, Mass./Bonn)

- Integrated Genome-Wide Pathway Association Analysis with INTERSNP: Herold, C. (Bonn); Mattheisen, M. (Bonn/Boston, Mass.); Lacour, A.; Vaitsiakhovich, T.; Angisch, M.; Drichel, D.; Becker, T. (Bonn)

- ARIEL and AMELIA: Testing for an Accumulation of Rare Variants Using Next-Generation Sequencing Data: Asimit, J.L.; Day-Williams, A.G. (Hinxton); Morris, A.P. (Oxford); Zeggini, E. (Hinxton)

- Linkage Analysis in the Next-Generation Sequencing Era: Bailey-Wilson, J.E.; Wilson, A.F. (Baltimore, Md.)

- Application of a Novel Score Test for Genetic Association Incorporating Gene-Gene Interaction Suggests Functionality for Prostate Cancer Susceptibility Regions: Ciampa, J. (Bethesda, Md./Oxford); Yeager, M.; Jacobs, K. (Frederick, Md.); Thun, M.J.; Gapstur, S. (Atlanta, Ga.); Albanes, D. (Bethesda, Md.); Virtamo, J. (Helsinki); Weinstein, S.J. (Bethesda, Md.); Giovannucci, E.; Willett, W.C. (Boston, Mass.); Cancel-Tassin, G.; Cussenot, 0.; Valeri, A. (Paris); Hunter, D. (Frederick, Md.); Hoover, R. (Bethesda, Md.); Thomas, G. (Lyon); Chanock, S. (Frederick, Md.); Holmes, C. (0xford); Chatterjee, N. (Bethesda, Md.)

- Modifiers and Subtype-Specific Analyses in Whole-Genome Association Studies: A Likelihood Framework: Lee, P.H.; Bergen, S.E.; Perlis, R.H. (Boston, Mass./ Cambridge, Mass.); Sullivan, P.F. (Chapel Hill, N.C.); Sklar, P. (New York, N.Y.); Smoller, J.W. (Boston, Mass./Cambridge, Mass.); Purcell, S.M. (Boston, Mass./Cambridge, Mass./New York, N.Y.)
Gathering original research reports and short communications from all over the world, Human Heredity is devoted to methodological and applied research on the genetics of human populations, association and linkage analysis, genetic mechanisms of disease, and new methods for statistical genetics, for example, analysis of rare variants and results from next generation sequencing. The value of this information to many branches of medicine is shown by the number of citations the journal receives in fields ranging from immunology and hematology to epidemiology and public health planning, and the fact that at least $50 \%$ of all Human Heredity papers are still cited more than 8 years after publication (according to ISI Journal Citation Reports). 


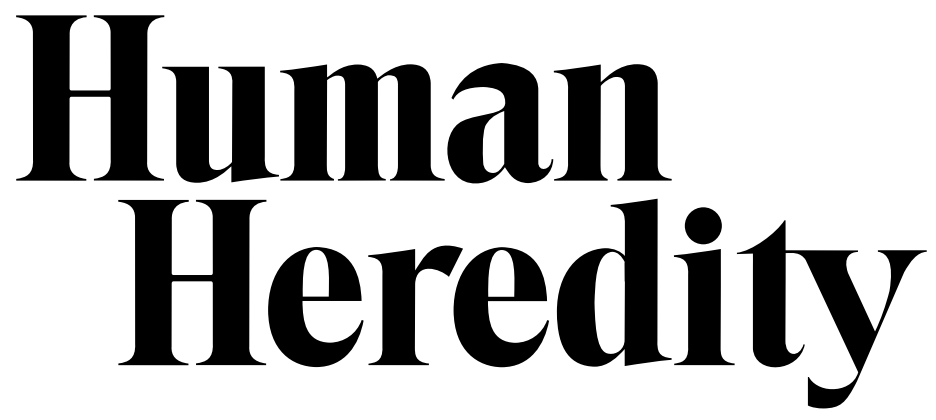

International Journal of Human and Medical Genetics

Founded 1948 as 'Acta Genetica et Statistica Medica' by

Gunnar Dahlberg (1948/1950-1964)

Continued in 1965 by M. Hauge (1965-1968)

Changed in 1969 to 'Human Heredity'

Continued in 1969 by M. Hauge and L. Beckman (1969-1983)

Continued in 1984 by L. Beckman (1984-1990)

Continued in 1991 by Jürg Ott (1991-2004)

Continued in 2005 by Marcella Devoto (2005-2012)

\section{Editor}

F. Clerget-Darpoux, Paris

Senior Editor

E. Génin, Brest

Editorial Administrator

K. Montague, New York, NY

\section{Associate Editors}

G. Barbujani, Ferrara

M. Boehnke, Ann Arbor, MI

L. Brzustowicz, Piscataway, NJ

M. de Andrade, Rochester, MN

M. Devoto, Philadelphia, PA

F. Dudbridge, London

D. Gordon, Piscataway, NJ

R. Kazma, San Francisco, CA

M. Knapp, Bonn

C. Lewis, London

Y.Y. Teo, Singapore

H.K. Tiwari, Birmingham, AL

V. Vieland, Columbus, $\mathrm{OH}$ 


\section{Invitation for Papers}

Only original papers written in English are considered and should be submitted using the online submission website at:

\section{www.karger.com/hhe}

If you have any questions, please contact the editorial office:

\section{katherine.montague@rockefeller.edu}

\section{Conditions}

Human Heredity publishes papers reporting on original investigations in the field of human and medical genetics. The journal will consider original papers and short communications as well as articles for the section 'Methodological Issues'. This section is intended for reports of a more technical nature. They need not in principle represent original research but may explain unusually difficult or little known problems, for example in segregation or linkage analysis. All manuscripts are subject to editorial review. Manuscripts are received with the explicit understanding that they are not under simultaneous consideration by any other publication. Submission of an article for publication implies the transfer of the copyright from the author to the publisher upon acceptance. Accepted papers become the permanent property of Human Heredity and may not be reproduced by any means, in whole or in part, without the written consent of the publisher. It is the author's responsibility to obtain permission to reproduce illustrations, tables, etc. from other publications.

Short communications: Communications not exceeding 2 printed pages will usually appear in print within 3-5 months.

\section{Arrangement}

Title page: The first page of each paper should indicate the title, the authors' names, the institute where the work was conducted, and a short title for use as running head.

Full address: The exact postal address of the corresponding author complete with postal code must be given at the bottom of the title page. Please also supply phone and fax numbers, as well as e-mail address.

Key words: Please supply 3-10 key words in English that reflect the content of the paper.

Abstract: Each paper needs an abstract of up to 200 words structured with subheadings as follows: Objective(s), Methods, Results, Conclusion(s).

Nomenclature, abbreviations and symbols: Authors should use HUGO Gene Nomenclature Committee (HGNC) -approved gene symbols for human genes. Please see http://www.genenames.org. Symbols for human genes not included in the above database should be obtained prior to manuscript submission from:
HUGO Gene Nomenclature Committee (HGNC) European Bioinformatics Institute (EMBL-EBI) Wellcome Trust Genome Campus

Hinxton, Cambridgeshire CB10 1SA, UK

Fax: +44 (0) 1223494468

E-Mail: hgnc@genenames.org

http://www.genenames.org

Authors should use SI units and follow the guidelines for abbreviation and symbols of the IUPACIUB Joint Commission on Biochemical Nomenclature. See Eur J Biochem 1970;15:203-208, corrected 1972;25:1, and for bases in nucleic acid sequences, Eur J Biochem 1985;150:1-5. All nonstandard abbreviations used in the text should be defined immediately before the first such abbreviation. For the mouse, see Lyon MF, Searle AG: Genetic Variants and Strains of the Laboratory Mouse. London, Oxford University Press, 1989. Authors should use HUGO Gene Nomenclature Committee (HGNC) approved gene symbols for human genes (http:// www.gene.ucl.ac.uk/nomenclature/). Symbols for human genes not found at the above website should be obtained prior to submission from the HUGO Gene Nomenclature Committee (HGNC), University College London, Wolfson House, 4 Stephenson Way, London NW1 2HE, UK, Tel. +44 207679 7410, Fax +44 207387 3496, E-Mail nome@galton. ucl.ac.uk. For guidelines see http://www.gene.ucl. ac.uk/nomenclature/guidelines.html and Wain et al: Guidelines for human gene nomenclature. Genomics 2002;79:464-470. Approved mouse nomenclature should be obtained prior to submission from Lois Maltais, The Jackson Laboratory, Bar Harbor ME 04609-0800, USA; Tel. +1 207288 6429; Fax +1 207288 6132; E-Mail nomen@informatics.jax. org; URL: http://www.informatics.jax.org/mgihome/nomen/.

Footnotes: Avoid footnotes. When essential, they are numbered consecutively and typed at the foot of the appropriate page.

Tables and illustrations: Tables and illustrations (both numbered in Arabic numerals) should be prepared on separate sheets. Tables require a heading and figures a legend, also prepared on a separate sheet. For the reproduction of illustrations, only good drawings and original photographs can be accepted; negatives or photocopies cannot be used. Due to technical reasons, figures with a screen background should not be submitted. When possible, group several illustrations on one block for reproduction (max. size $180 \times 223 \mathrm{~mm}$ ) or provide crop marks. On the back of each illustration, indicate its number, the author's name, and 'top' with a soft pencil. Electronically submitted b/w half-tone and color illustrations must have a final resolution of $300 \mathrm{dpi}$ after scaling, line drawings one of 800 1,200 dpi.

Color illustrations

Online edition: Color illustrations are reproduced free of charge. In the print version, the illustrations are reproduced in black and white. Please avoid referring to the colors in the text and figure legends. Print edition: Up to 6 color illustrations per page can be integrated within the text at CHF 800.- per page.

References: In the text identify references by Arabic numerals [in square brackets]. Material submitted for publication but not yet accepted should be noted as [unpublished data] and not be included in the reference list. The list of references should include only those publications which are cited in the text. Do not alphabetize; number references in the order in which they are first mentioned in the text. The surnames of all authors followed by initials should be given. There should be no punctuation other than a comma to separate the authors. Preferably, please cite all authors. Abbreviate journal names according to the Index Medicus system. Also see International Committee of Medical Journal Editors: Uniform requirements for manuscripts submitted to biomedical journals (www.icmje.org).

\section{Examples}

(a) Papers published in periodicals: Sun J, Koto $\mathrm{H}$, Chung KF: Interaction of ozone and allergen challenges on bronchial responsiveness and inflammation in sensitised guinea pigs. Int Arch Allergy Immunol 1997;112:191-195.

(b) Papers published only with DOI numbers:

Theoharides TC, Boucher W, Spear K: Serum interleukin-6 reflects disease severity and osteoporosis in mastocytosis patients. Int Arch Allergy Immunol DOI: 10.1159/000063858.

(c) Monographs: Matthews DE, Farewell VT: Using and Understanding Medical Statistics, ed 3, revised. Basel, Karger, 1996.

(d) Edited books: Parren PWHI, Burton DR: Antibodies against HIV-1 from phage display libraries: Mapping of an immune response and progress towards antiviral immunotherapy; in Capra JD (ed): Antibody Engineering. Chem Immunol. Basel, Karger, 1997, vol 65, pp 18-56.

Reference Management Software: Use of EndNote is recommended for easy management and formatting of citations and reference lists.

\section{Digital Object Identifier (DOI)}

S. Karger Publishers supports DOIs as unique identifiers for articles. A DOI number will be printed on the title page of each article. DOIs can be useful in the future for identifying and citing articles published online without volume or issue information. More information can be found at www.doi.org.

\section{Supplementary Material}

Supplementary material is restricted to additional data that are not necessary for the scientific integrity and conclusions of the paper. Please note that all supplementary files will undergo editorial review and should be submitted together with the original manuscript. The Editors reserve the right to limit the scope and length of the supplementary material. Supplementary material must meet produc-

\section{KARGER}

E-Mail karger@karger.com www.karger.com
(C) 2013 S. Karger AG, Basel 


\section{Human Heredity}

tion quality standards for Web publication without the need for any modification or editing. In general, supplementary files should not exceed $10 \mathrm{Mb}$ in size. All figures and tables should have titles and legends and all files should be supplied separately and named clearly. Acceptable files and formats are: Word or PDF files, Excel spreadsheets (only if the data cannot be converted properly to a PDF file), and video files (.mov, .avi, .mpeg)

\section{Author's Choice ${ }^{\mathrm{TM}}$}

Karger's Author's Choice ${ }^{\mathrm{TM}}$ service broadens the reach of your article and gives all users worldwide free and full access for reading, downloading and printing at www.karger.com. The option is available for a one-time fee of CHF 3,000.-, which is a permissible cost in grant allocation. More information can be found at www.karger.com/authors_choice.

\section{NIH-Funded Research}

The U.S. National Institutes of Health (NIH) mandates under the NIH Public Access Policy that final, peer-reviewed manuscripts appear in its digital database within 12 months of the official publication date. As a service to authors, Karger submits the final version of your article on your behalf to PubMed Central. For those selecting our premium Author's Choice $^{\mathrm{TM}}$ service, we will send your article immediately upon publishing, accelerating the accessibility of your work without the usual embargo. More details on NIH's Public Access Policy is available at http://publicaccess.nih.gov/policy.htm

\section{Self-Archiving}

Karger permits authors to archive their pre-prints (i.e. pre-refereeing) or post-prints (i.e. final draft post-refereeing) on their personal or institution's servers, provided the following conditions are met: Articles may not be used for commercial purposes, must be linked to the publisher's version, and must acknowledge the publisher's copyright. Authors selecting Karger's Author's Choice ${ }^{\mathrm{TM}}$ feature, however, are also permitted to archive the final, published version of their article, which includes copyediting and design improvements as well as citation links.

\section{Page Charges}

There is a page charge of CHF 75.- per page (including tables, illustrations and references). One printed page is equal to approximately 3 manuscript pages.

\section{Electronic Proofs}

Unless indicated otherwise, proofs will be e-mailed to the corresponding author.

\section{Reprints}

Order forms and a price list are sent with the proofs. Orders submitted after the issue is printed are subject to considerably higher prices.

\section{New!}

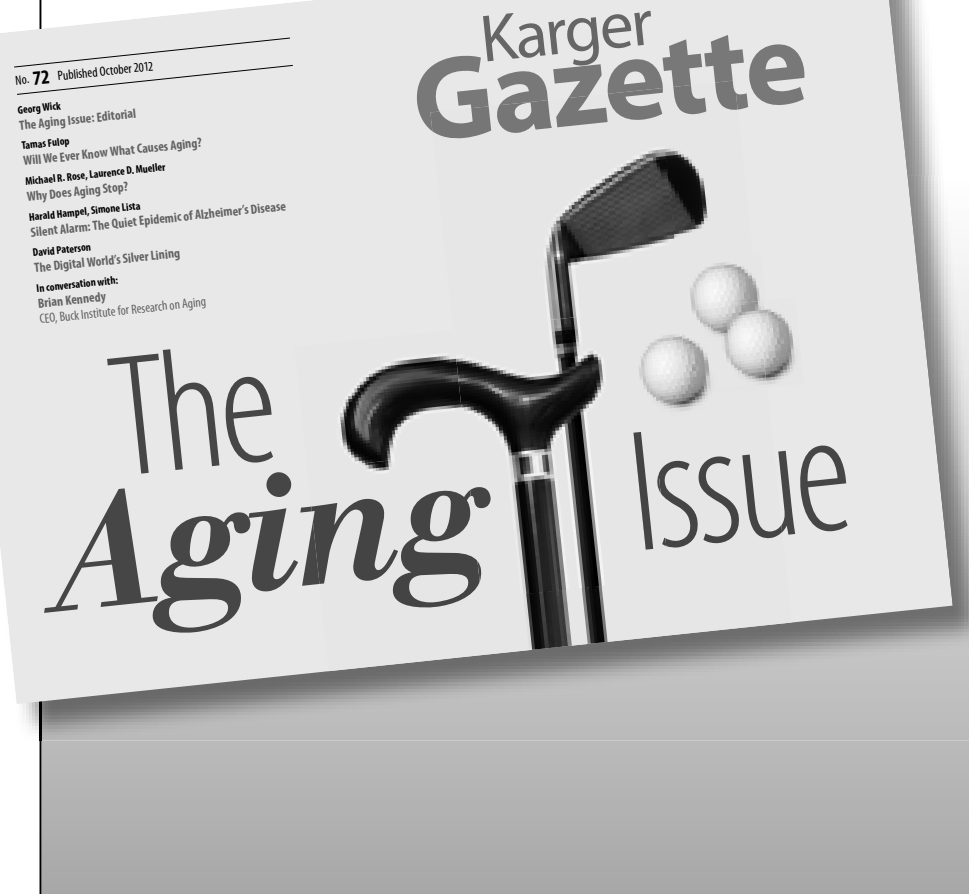

For over 40 years the Karger Gazette has been distributed to a growing audience worldwide. Published once a year in newspaper format, it highlights advances in biomedicine and clinical practice, introduces personalities, portrays research institutes and chronicles milestones in the history of Karger Publishers in a lively and readable style. With invited contributions by experts from all over the world, each issue is devoted to a special topic of current interest.

In the latest issue, read free articles on the causes of the aging process, why aging stops in later adult life, the quiet epidemic of Alzheimer's Disease, internet use by seniors, and more.

For your free print subscription $\rightarrow$ gazette@karger.com

Read it online $\rightarrow$ www.karger.com/gazette

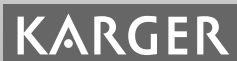

S. Karger AG

Medical and Scientific Publishers

Karger Gazette

Allschwilerstrasse 10

CH-4009 Basel

Switzerland

www.karger.com

\section{KARGER}

E-Mail karger@karger.com www.karger.com
(C) 2013 S. Karger AG, Basel

The Journal Home Page is available at: www.karger.com/hhe 


\section{Human Heredity}

ISSN Print Edition: 0001-5652 ISSN Online Edition: 1423-0062

Journal Homepage: www.karger.com/hhe

Publication Data: 'Human Heredity' is published 8 times a year. Volumes 75,76 , each with 4 issues, appear in 2013

Copyright: (c) 2013 S. Karger AG, Basel (Switzerland) All rights reserved. No part of this publication may be translated into other languages, reproduced or utilized in any form or by any means, electronic or mechanical including photocopying, recording, microcopying, or by any information storage and retrieval system, without permission in writing from the publisher or, in the case of photocopying, direct payment of a specified fee to the Copyright Clearance Center.

Disclaimer: The statements, opinions and data contained in this publication are solely those of the individual authors and contributors and not of the publisher and the editor(s). The appearance of advertisements in the journal is not a warranty, endorsement, or approval of the products or services advertised or of their effectiveness, quality or safety. The publisher and the editor(s) disclaim responsibility for any injury to persons or property resulting from any ideas, methods, instructions or products referred to in the content or advertisements.
Subscription Rates: Subscriptions run for a full calendar year. Prices are given per year. Personal subscription:

Print or Online

CHF 1460.-

EUR 1178.-

USD 1446.00

Print+Online combined CHF 1556.-

EUR 1256.-

(added to print and print+online)

P 57.60 Europe, CHF 83.20 Overseas

EUR 44.80

USD 76.80

Institutional subscription:

Print or Online

Print+Online combined

CHF 2920.

EUR 2354.-

CHF 3212.-

USD 2892.00

postage and handling (added to print and print+online)

CHF 72.- Europe, CHF 104.- Overseas

EUR 56.-

USD 96.00

Airmail surcharge: CHF 70.- / USD 66.00
Back Volumes and Single Issues: Information on availability and prices of single print issues and print or electronic back volumes can be obtained from Customer Service at service@karger.ch.

Bibliographic Indices: This journal is regularly listed in bibliographic services, including Current Contents ${ }^{\circledR}$ and PubMed/MEDLINE.

Photocopying: This journal has been registered with the Copyright Clearance Center (CCC), as indicated by the code appearing on the first page of each article. For readers in the US, this code signals consent for copying of articles for personal or internal use, or for the personal or internal use of specific clients, provided that the stated fee is paid per copy directly to

Copyright Clearance Center Inc.

222 Rosewood Drive

Danvers, MA 01923 (USA)

A copy of the first page of the article must accompany payment. Consent does not extend to copying for general distribution, for promotion, for creating new works, or for resale. In these cases, specific written permission must be obtained from the copyright owner,

S. Karger AG, P.O. Box

CH-4009 Basel (Switzerland).
Subscription Orders:

Orders can be placed at agencies,

bookstores, directly with the Publisher

\section{S. Karger AG}

Medical and Scientific Publishers

Allschwilerstrasse 10

$\mathrm{CH}-4009$ Basel

Switzerland

$\mathrm{t}:+41613061111$

f: +41613061234

e: karger@karger.com

w: www.karger.com

(for courier services only:

Allschwilerstrasse 10

$\mathrm{CH}-4055$ Basel)

or further Karger offices
or representatives:
Germany
S. Karger GmbH
Postfach
79095 Freiburg
Deutschland
(Hausadresse: Wilhelmstrasse 20A,
79098 Freiburg)
t: +49 761 452070
f: +497614520714
e: information@karger.de
w: www.karger.de
Japan
Karger Japan, Inc.
Shiba Daimon Asahi Bldg. 2F
1-2-23 Shiba Daimon
Minato-ku
Tokyo $105-0012$
Japan
t: +81 364356242
f: +81 364356244
e: publisher@karger.jp
w: www.karger.jp

USA

S. Karger Publishers, Inc.

26 West Avon Road

P.O. Box 529

Unionville, CT 06085

USA

Toll free: +18008285479

t: +18606757834

f: +18606757302

e: karger@snet.net

France

Librairie Médi-Sciences Sar 36, bd de Latour-Maubourg 75007 Paris

France

$\mathrm{t}:+33(0) 145514258$

f: $+33(0) 145560780$

e: librairie@medi-sciences.fr

w: www.medi-sciences.fr

Change of Address:

Both old and new address should be sent

to the subscription source.

South East Asia, China and Taiwan

Karger Regional Office (Malaysia)

CEO Suite Kuala Lumpur

Quill 7, 27th Floor

Jalan Stesen Sentral 5

KL Sentral

Kuala Lumpur 50470

Malaysia

t: +60327766803

f: +60327766999

e: service@karger.cn; r.chew@karger.cn

\section{Karger China}

10th Floor, Twin Towers (East)

B12 Jianguomenwai Avenue

Beijing 100022

China

t: +861051235033

f: +861051235122

e: service@karger.cn; r.chew@karger.cn

w: www.karger.cn

India, Bangladesh, Sri Lanka

Medscience India

Plot No. 17, Yusuf Sarai Market

B.L. Glass Building, 2nd Floor

Sri Aurobindo Marg

New Delhi 110016

India

t: +911146029633

f: +911146029634

c: +919891052128

e: r.kumar@karger.com

\section{KARGER}

E-Mail karger@karger.com www.karger.com
(C) 2013 S. Karger AG, Basel

The Guidelines for Authors are available at: www.karger.com/hhe_Guidelines 


\section{Contents}

See the journal website for contents

KARGER Basel $\bullet$ Freiburg $\cdot$ Paris $\bullet$ London $\bullet$ New York $\cdot$ New Delhi $•$ Bangkok Beijing $\cdot$ Tokyo $\cdot$ Kuala Lumpur $\cdot$ Singapore $\bullet$ Sydney 


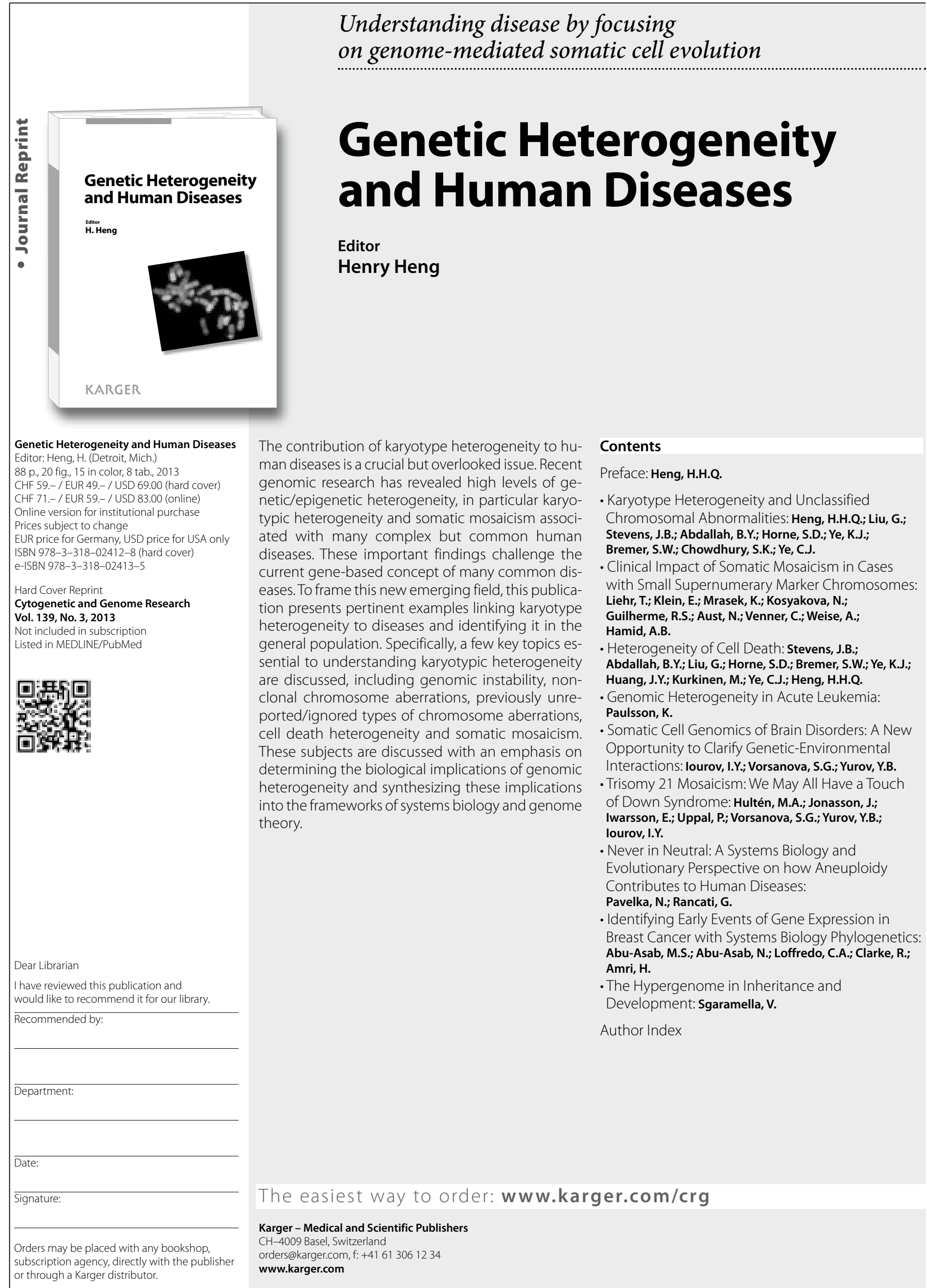




\title{
Journal of \\ Nutrigenetics \\ Nutrigenomics
}

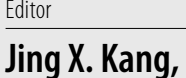 \\ Boston, Mass.
}

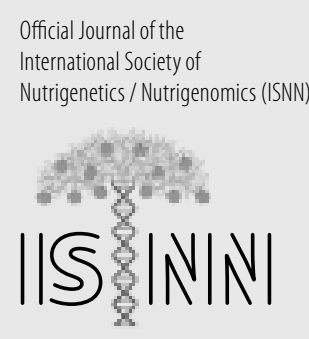

\section{Nutrigenetics Nutrigenomics}

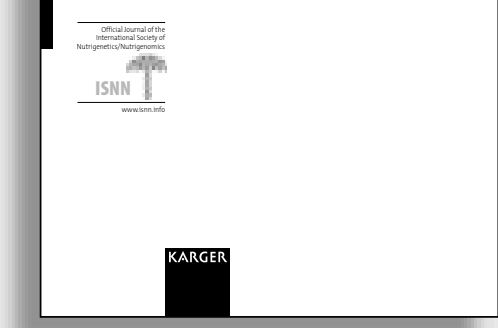

\section{More information at}

\section{www.karger.com/jnn}

- Pay-per-View and Subscriber Access to Full Text

- Full Table of Contents

- Full Editorial Board

- Free Abstracts and Selected Articles

- Online Sample Issue

- Submission/Guidelines for Authors

- Subscription Details

- Free Alert Service

- Online Library Recommendation

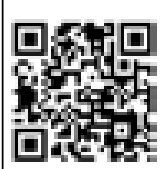

Journal of Nutrigenetics and

Nutrigenomics

2014: Volume 7

6 issues per volume

Language: English

ISSN 1661-6499 (print)

ISSN 1661-6758 (online)

\section{Selected contributions}

- The Emerging Role of MicroRNAs in the Regulation of Gene Expression by

Nutrients: García-Segura, L.; Pérez-Andrade, M.; Miranda-Ríos, J. (México)

- Associations between Polymorphisms in Genes Involved in Fatty Acid

Metabolism and Dietary Fat Intakes: Bouchard-Mercier, A.; Paradis, A.-M.;

Pérusse, L.; Vohl, M.-C. (Quebec, Que.)

- Identification of Metabolic Biomarkers for Personalized Nutrition: Kang, J.X.

(Boston, Mass.)

- Rat Chromosome 8 Confers Protection against Dyslipidemia Caused by a

High-Fat/Low-Carbohydrate Diet: Solberg Woods, L.C. (Milwaukee, Wisc.); Woods, B.C.

(Whitewater, Wisc.); Leitschuh, C.M.; Laurie, S.J. (Beloit, Wisc.); Jacob, H.J. (Milwaukee, Wisc.)

- Vitamin E Alters Inflammatory Gene Expression in Alcoholic Chronic Pancreatitis:

Monteiro, T.H.; Siqueira Silva, C.; Cordeiro Simões Ambrosio, L.M.; Zucoloto, S.;

Vannucchi, H. (Ribeirão Preto)

- Copy Number Polymorphism of the Salivary Amylase Gene: Implications in

Human Nutrition Research: Santos, J.L. (Santiago); Saus, E. (Barcelona); Smalley, S.V.;

Cataldo, L.R.; Alberti, G. (Santiago); Parada, J. (Valdivia); Gratacòs, M.; Estivill, X.

(Barcelona)

- Cannabinoid Type 1 Receptor Gene Polymorphism and Macronutrient Intake:

Caruso, M.G. (Castellana Grotte); Gazzerro, P. (Fisciano); Notarnicola, M.; Cisternino, A.M.;

Guerra, V.; Misciagna, G. (Castellana Grotte); Laezza, C. (Naples); Bifulco, M. (Fisciano)

- The Influence of Vitamin A Supplementation on Foxp3 and TGF- $\beta$ Gene

Expression in Atherosclerotic Patients: Mottaghi, A.; Salehi, E.; Keshvarz, A.;

Sezavar, H.; Saboor-Yaraghi, A.-A. (Tehran)
The emerging field of nutrigenetics and nutrigenomics is rapidly gaining importance, and this new international journal has been established to meet the needs of the investigators for a highquality platform for their research. Endorsed by the recently founded 'International Society of Nutrigenetics/Nutrigenomics' (ISNN), the Journal of Nutrigenetics and Nutrigenomics welcomes contributions not only investigating the role of genetic variation in response to diet and that of nutrients in the regulation of gene expression, but is also open for articles covering all aspects of gene-environment interactions in the determination of health and disease. Original papers and reviews cover the genetic basis for the variable responses to diet and lifestyle factors in chronic conditions (e.g. cardiovascular disease, obesity, diabetes, cancer), methods to assess gene-environment interactions and other related relevant topics, with research drawing from both human and animal studies. 


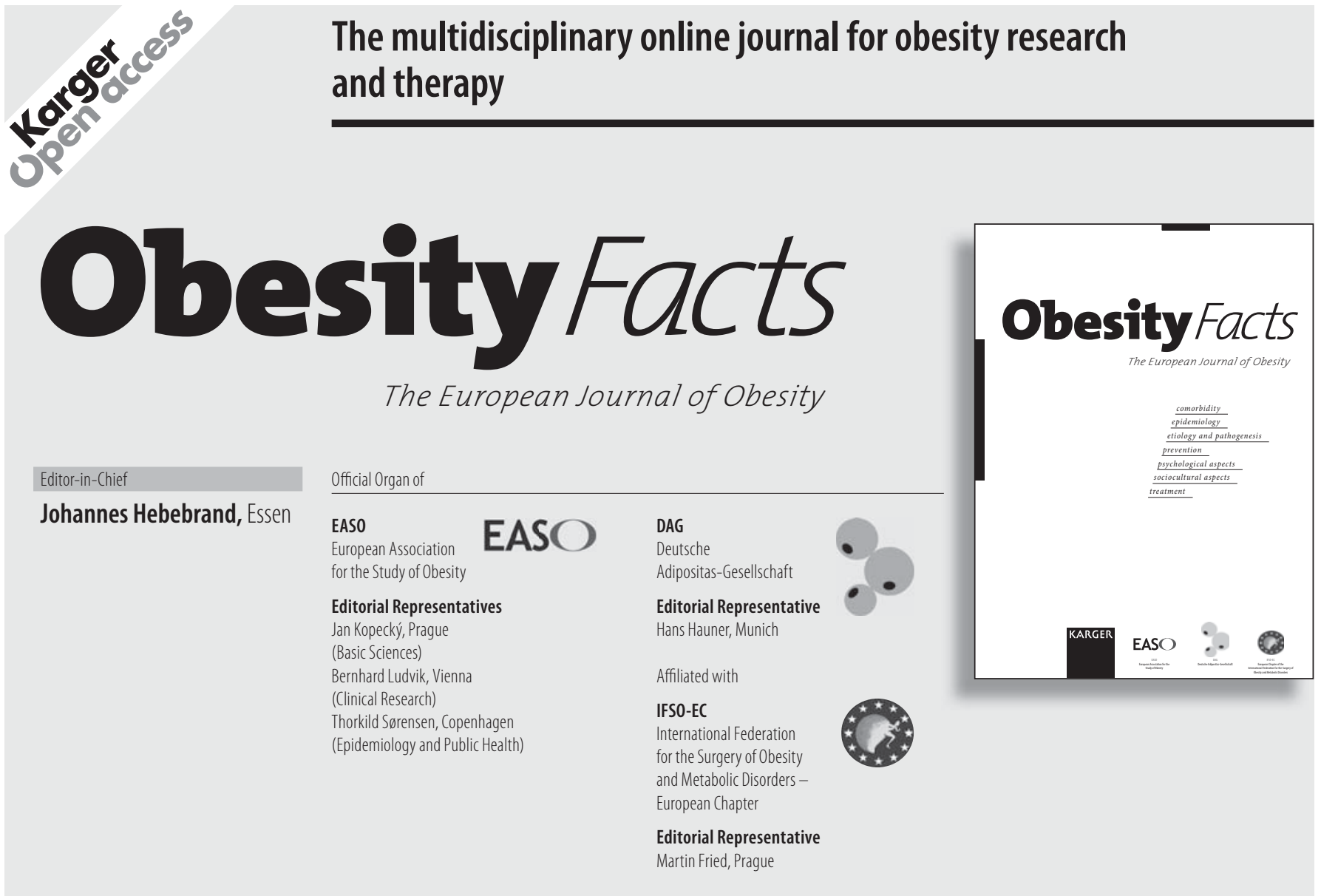

More information at

www.karger.com/ofa

- Full Table of Contents

- Full Editorial Board

- Submission / Guidelines for Authors

- Free Alert Service

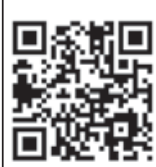

Obesity Facts

2013: Volume 6 with 6 issues

6 issues per year

Language: English

ISSN 1662-4025

ISSN online 1662-4033

Listed in bibliographic services including Science Citation Index Expanded/Scisearch, Current Contents ${ }^{\circledR} /$ Clinical Medicine, PubMed/ MEDLINE, Journal Citation Reports/

Science Edition

\section{Selected contributions}

- Overweight Prevention Implemented by Primary School Teachers: A Randomised Controlled Trial: Brandstetter, S.; Klenk, J.; Berg, S.; Galm, C. (Ulm); Fritz, M. (Bejm); Peter, R.; Prokopchuk, D.; Steiner, R.P.; Wartha, 0.; Steinacker, J.; Wabitsch, M. (Ulm)

- Leptin in Early Life: A Key Factor for the Development of the Adult Metabolic

Profile: Granado, M.; Fuente-Martín, E.; García-Cáceres, C.; Argente, J.; Chowen, J.A. (Madrid)

- Genetic and Environmental Dissections of Sub-Phenotypes of Metabolic Syndrome in the Chinese Population: A Twin-Based Heritability Study: Duan, $\mathbf{H}_{. ;}$ Pang, Z.; Zhang, D. (Qingdao); Li, S.; Kruse, T.A.; Kyvik, K.0.; Christensen, K.; Tan, Q. (Odense)

- Body Mass Index and Cognitive Ability of Young Children: Veldwijk, J.;

Scholtens, S. (Bilthoven); Hornstra, G. (Maastricht); Bemelmans, W.J.E. (Bilthoven)

- Evaluation of the Obesity Genes FTO and MC4R and the Type 2 Diabetes Mellitus Gene TCF7L2 for Contribution to Stroke Risk: The Mannheim-Heidelberg Stroke

Study: Winter, Y. (Marburg); Back, T. (Arnsdorf); Scherag, A. (Essen); Linseisen, J. (Heidelberg/Neuherberg); Rohrmann, S. (Heidelberg); Lanczik, 0. (Mannheim); Hinney, A.; Scherag, S. (Essen); Neumaier, M. (Mannheim); Ringleb, P.A. (Heidelberg)

- Reduced Brain Natriuretic Peptide Levels in Class III Obesity: The Role of Metabolic and Cardiovascular Factors: Beleigoli, A.; Diniz, M.; Nunes, M.; Barbosa, M.; Fernandes, S.; Abreu, M.; Ribeiro, A. (Belo Horizonte)

- Worksite Physical Activity Interventions and Obesity: A Review of European Studies (the HOPE Project): Vuillemin, A. (Bobigny/Nancy); Rostami, C. (Bobigny); Maes, L.; Van Cauwenberghe, E. (Ghent); Van Lenthe, F. (Rotterdam); Brug, J. (Amsterdam); De Bourdeaudhuij, I. (Ghent); Oppert, J.M. (Bonogny/Paris)

- Banded Sleeve Gastrectomy Using the GABP Ring - Surgical Technique: Karcz, W.K.; Marjanovic, G.; Grueneberger, J.; Baumann, T. (Freiburg i.Br.); Bukhari, W. (Jeddah); Krawczykowski, D. (Chalons en Champagne); Kuesters, S. (Freiburg i.Br.)

\section{Aims and Scope}

Obesity Facts publishes articles covering all aspects of obesity, in particular epidemiology, etiology and pathogenesis, treatment, and the prevention of adiposity. As obesity is related to many disease processes, the journal is also dedicated to all topics pertaining to comorbidity and covers psychological and sociocultural aspects as well as influences of nutrition and exercise on body weight. The editors carefully select papers to present only the most recent findings in clinical practice and research. All professionals concerned with obesity issues will find this journal a most valuable update to keep them abreast of the latest scientific developments.

Special sections comprising a variety of subspecialties reinforce the journal's value as an exhaustive record of recent progress for all internists, gastroenterologists, endocrinologists, pediatricians, dieticians, nutritionists, bariatric surgeons, psychologists and psychiatrists, occupational health practitioners, sports medicine specialists, ecotrophologists, sociologists, and biologists as well as prevention and public health researchers. In addition, Obesity Facts serves as an ideal information tool for the members of the pharmaceutical and food industry as well as those active in nutritional research and medicine. 


\section{Human Heredity}

\section{Genes and the Environment in Obesity}

This publication pulls together work from more than a dozen leading obesity, energetics, and nutrition researchers working on genetic and genomic aspects of obesity. Their contributions present the latest findings from randomized controlled trials and other ongoing investigations, and direct our focus towards future genetics and epigenetic targets in our struggle with the obesity epidemic in the USA and across the globe. The topics considered range from ancestral admixture to assortative mating, from functional analysis to genome-wide association studies, and from satiety to brain anatomy. This compilation of reviews and methodological developments will help the reader to achieve a broader appreciation of the complexities of this field as well as a deeper understanding of its latest advances and important next steps. 